\title{
Overexploitation and water quality in the Crevillente aquifer (Alicante, SE Spain)
}

\author{
J. M. Andreu ${ }^{1}$, A. Pulido-Bosch ${ }^{2}$, M. R. Llamas ${ }^{3}$, C. Bru ${ }^{4}$, \\ P. Martínez-Santos ${ }^{5}$, E. García-Sánchez ${ }^{6} \&$ L. Villacampa ${ }^{1}$ \\ ${ }^{1}$ Department of Earth and Environmental Sciences, \\ University of Alicante, Spain \\ ${ }^{2}$ Department of Hydrogeology, University of Almeria, Spain \\ ${ }^{3}$ Royal Academy of Sciences, Madrid, Spain \\ ${ }^{4}$ Department of Regional Geographic Analysis and Physical Geography, \\ University of Alicante, Spain \\ ${ }^{5}$ Department of Geology, University Complutense, Madrid, Spain \\ ${ }^{6}$ Department of Agrochemistry, University Miguel Hernández, Spain
}

\begin{abstract}
The Crevillente aquifer is a karstic aquifer, situated in Alicante province in the SE of Spain. The aquifer basically comprises a series of Jurassic limestones and dolomites, belonging to the Betic Cordillera. Intense exploitation of the aquifer started in the early 1960s. Exploitation was initially concentrated in two sectors of the Sierra de Crevillente and, years later, extended to a third sector. As a consequence of abstractions that were much greater than recharge into the system, a continual drop in the water level persisted for several decades. These abstractions have occasionally caused local dewatering over depths of more than $300 \mathrm{~m}$. From a hydrogeological point of view, the aquifer dewatering in one of the sectors was accompanied by increased mineralization and a fall in quality of the groundwater, and several boreholes had to be abandoned. In recent years, the degree to which the aquifer is overexploited has fallen considerably, and it appears to have entered a new hydrodynamic stage. New hydrogeochemical characterisations have been carried out, which indicate that the aquifer water is relatively strongly mineralised due, fundamentally, to the dissolution of evaporite rocks. On the other hand, deterioration in water quality as a consequence of the degree of overabstraction can also be confirmed.

Keywords: overexploitation, hydrogeochemistry, water quality, karstic aquifer, Crevillente.
\end{abstract}




\section{Introduction}

The Crevillente aquifer is located in Alicante province in south-eastern Spain. It covers a surface area of approximately $140 \mathrm{~km}^{2}$. Intense exploitation of this aquifer began in the sixties, when a private company decided to tap its waters via a gallery in the southern part of the aquifer. It is estimated that water from the aquifer is mainly used for the irrigation of approximately 9000 hectares, PulidoBosch et al [10], dedicated principally to the cultivation of table grapes and, in smaller measure, other fruit and market garden vegetables.

The intensity of abstractions increased year on year and this, together with the scarce recharge, caused significant dewatering that could really be viewed as water mining. The persistence of this situation over several decades has unleashed a series of hydrogeological, environmental, economic and social consequences, Pulido-Bosch [9], Pulido-Bosch et al [10]; Andreu et al [3]; Custodio [7]. From a hydrogeological viewpoint, the most relevant effects are: pronounced descent of piezometric levels, deterioration in water quality and loss of yield, together with abandonment of boreholes. The extreme overabstraction of the aquifer drew the Administration to provisionally declare it overexploited in 1987, Aragonés et al [5]; Corchón et al [6].

In recent years abstractions have been reduced. Given this new situation, the principal aims of this study were twofold: first, to undertake an up-to-date characterisation of the aquifer following more than forty years of intense abstractions; and second, by reviewing the hydrogeochemical data collected over recent years, to establish the extent to which overexploitation has affected water quality throughout the aquifer.

\section{Hydrogeological setting}

Crevillente aquifer forms part of the Betic Cordillera. The aquifer is formed by a sequence of carbonate deposits more than $500 \mathrm{~m}$ in thickness, which include dolomite, dolomitic limestone and limestone that date from the Lower Liassic to Upper Jurassic. This carbonate series, affected by folding, gives rise to various mountain reliefs and depressions. The relief is formed mainly by carbonate rocks, whilst in the depressions are Cretaceous marl over a Jurassic carbonate sequence. The Cretaceous marl could act as the impermeable ceiling top, Solís et al [11]. Everything points to the basal impermeable layer being formed by Triassic clay and evaporite rocks associated with a thrust fault, or by a band of impermeable, silty-clayey limestone dolomite that has resulted from the crushing that the aquifer rocks in the zone of the thrust fault, Andreu [1].

The climate of the region in which the Crevillente aquifer is located is considered to be semi-arid with Mediterranean characteristics. Mean precipitation is between 290 and $360 \mathrm{~mm}$. Recharge to the aquifer corresponds basically to effective precipitation over outcrops of permeable rock. It is not precisely known, though is estimated near $10 \mathrm{hm}^{3} /$ year. 


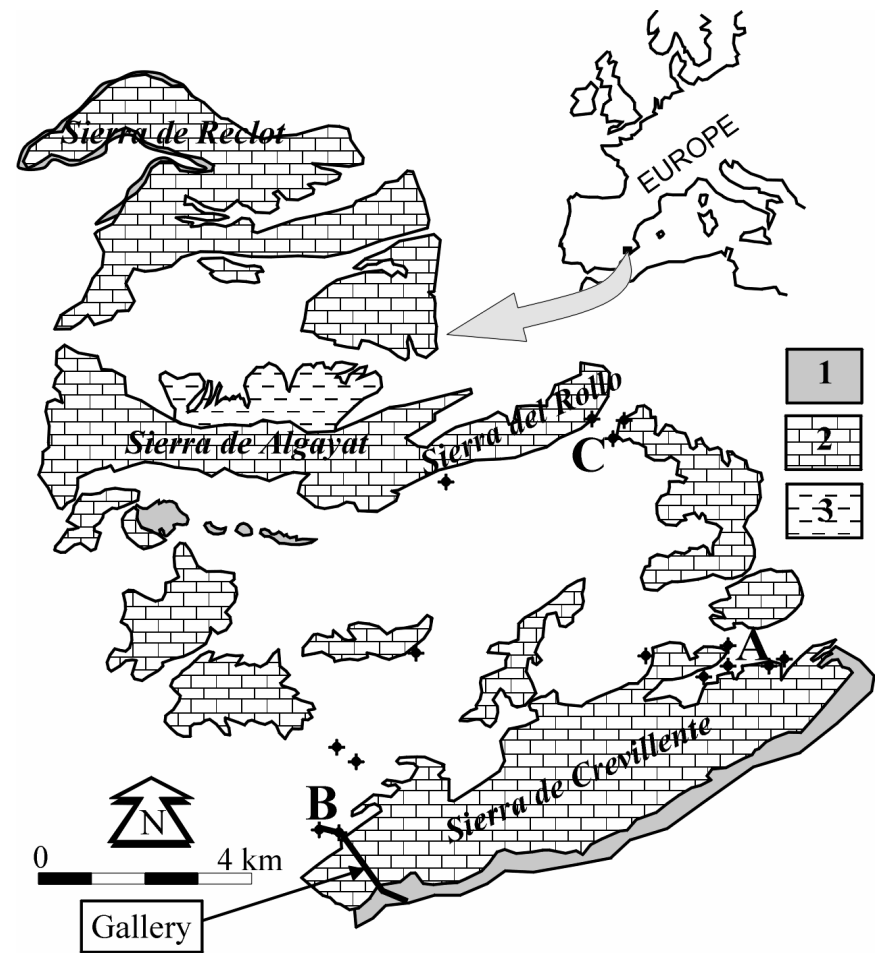

Figure 1: Hydrogeological setting of the Sierra de Crevillente aquifer and its surroundings. Legend: 1. Keuper deposits; 2. Jurassic limestones and dolomites; 3. Cretaceous marls. A: Tolomo area abstractions. B: Galería area abstractions. C: Sierra del Rollo area abstractions.

The first abstractions on the aquifer were made in the Sierra de Crevillente, in Tolomó area, sector A in figure 1; and Galería area, sector B in the same figure. In the end various boreholes were also drilled in other parts of the aquifer, including on the eastern edge the Sierra del Rollo, area $\mathrm{C}$ in figure 1. The pumped abstractions got up to $30 \mathrm{hm}^{3}$ some year. But in recent years there has been an estimated mean abstraction of between 5 and $7 \mathrm{hm}^{3} /$ year.

In terms of the piezometric changes, the greatest falls in water level have occurred in the eastern sector. In total, a band of more than $300 \mathrm{~m}$ of the aquifer has been depleted in this sector. In the western sector and in Rollo sector the fall in levels has been lower. Dating from about a decade ago, variations in piezometric level have been depleted. This new situation is largely due to the high number of boreholes that have been abandoned.

\section{Chemical composition of the water}

To characterise the current hydrogeochemistry of this aquifer, an attempt was made to compile as much analytical data as possible for the period 2000/05, and 
Table 1: $\quad$ Summary of the hydrochemistry for samples for the periods $2000-$ 2005 and prior to 1983 (M: mean; SD: standard deviation; Max. Maximum; Min: Minimum; Conductivity: $\mu \mathrm{Scm}^{-1}$; ions: $\mathrm{mg} \mathrm{L}^{-1}$ ).

\begin{tabular}{|c|c|c|c|c|c|c|c|c|c|c|c|c|c|c|c|c|}
\hline \multicolumn{17}{|c|}{ A. Between 2000 and 2005} \\
\hline & \multicolumn{4}{|c|}{$\begin{array}{c}\text { Aquifer } \\
32 \text { samples }\end{array}$} & \multicolumn{4}{|c|}{$\begin{array}{l}\text { Sector A } \\
8 \text { samples }\end{array}$} & \multicolumn{4}{|c|}{$\begin{array}{c}\text { Sector B } \\
8 \text { samples }\end{array}$} & \multicolumn{4}{|c|}{$\begin{array}{c}\text { Sector C } \\
9 \text { samples }\end{array}$} \\
\hline & M & SD & Max & Min & $\mathbf{M}$ & SD & Max & Min & $\mathbf{M}$ & SD & Max & Min & M & SD & Max & Min \\
\hline$E C$ & 2303 & 900 & 4000 & 942 & 3044 & 456 & 4000 & 2600 & 2958 & 156 & 3130 & 2640 & 1006 & 48 & 1100 & 942 \\
\hline$p H$ & 7.5 & 0.3 & 8.4 & 7 & 7.6 & 0.4 & 8.4 & 7.2 & 7.5 & 0.1 & 7.6 & 7.4 & 7.5 & 0.2 & 7.7 & 7.1 \\
\hline $\mathrm{Ca}^{2+}$ & 126 & 38 & 182 & 70 & 131 & 30 & 180 & 100 & 169 & 11 & 182 & 150 & 79 & 12 & 100 & 60 \\
\hline $\mathrm{Mg}^{2+}$ & 48 & 11 & 64 & 30 & 51 & 7 & 64 & 43 & 58 & 2 & 60 & 56 & 29 & 2 & 30 & 26 \\
\hline $\mathrm{Na}^{+}$ & 362 & 132 & 575 & 95 & 449 & 82 & 575 & 345 & 409 & 20 & 438 & 377 & 102 & 19 & 135 & 81 \\
\hline $\boldsymbol{K}^{+}$ & - & - & - & - & - & - & - & - & 6.3 & 0.3 & 6.8 & 5.8 & 1.8 & 0.4 & 2 & 1 \\
\hline $\mathrm{HCO}_{3}^{-}$ & 214 & 15 & 250 & 183 & 210 & 14 & 232 & 183 & 202 & 10 & 222 & 194 & 229 & 11 & 250 & 210 \\
\hline $\mathrm{SO}_{4}^{2-}$ & 342 & 135 & 530 & 105 & 353 & 52 & 446 & 283 & 492 & 30 & 530 & 446 & 122 & 14 & 150 & 105 \\
\hline$C l$ & 512 & 207 & 966 & 135 & 670 & 141 & 966 & 525 & 624 & 28 & 648 & 577 & 150 & 14 & 171 & 135 \\
\hline $\mathrm{NO}_{3}^{-}$ & - & - & - & - & - & - & - & - & 7 & 0.2 & 7.4 & 6.8 & 6.4 & 1.1 & 8 & 5 \\
\hline \multicolumn{17}{|c|}{ B. Before the year 1983} \\
\hline & \multicolumn{4}{|c|}{$\begin{array}{c}\text { Aquifer } \\
56 \text { samples }\end{array}$} & \multicolumn{4}{|c|}{$\begin{array}{c}\text { Sector A } \\
46 \text { samples }\end{array}$} & \multicolumn{4}{|c|}{$\begin{array}{l}\text { Sector B } \\
5 \text { samples }\end{array}$} & \multicolumn{4}{|c|}{$\begin{array}{l}\text { Sector C } \\
5 \text { samples }\end{array}$} \\
\hline & M & SD & Max & Min & M & SD & $\operatorname{Max}$ & Min & M & SD & Max & Min & M & SD & Max & Min \\
\hline$E C$ & 1727 & 488 & 2800 & 751 & 1803 & 488 & 2800 & 1115 & 2006 & 198 & 2346 & 2066 & 841 & 79 & 984 & 751 \\
\hline$p H$ & 7.6 & 0.3 & 8.7 & 6.7 & 7.6 & 0.3 & 8.7 & 6.7 & 7.8 & 0.1 & 7.9 & 7.7 & 7.5 & 0.4 & 8 & 7 \\
\hline $\mathrm{Ca}^{2+}$ & 98 & 28 & 200 & 36 & 96 & 28 & 154 & 36 & 142 & 36 & 200 & 112 & 66 & 16 & 84 & 47 \\
\hline $\mathrm{Mg}^{2+}$ & 59 & 21 & 114 & 29 & 62 & 21 & 114 & 29 & 47 & 4 & 51 & 41 & 39 & 4 & 44 & 32 \\
\hline $\mathrm{Na}^{+}$ & 214 & 81 & 401 & 65 & 222 & 81 & 401 & 80 & 294 & 18 & 321 & 281 & 76 & 15 & 100 & 65 \\
\hline $\boldsymbol{K}^{+}$ & 3.8 & 1 & 7.7 & 1.8 & 3.8 & 1 & 7.7 & 2 & 4.4 & 0.7 & 5.5 & 4 & 2.6 & 1.1 & 3.8 & 1.8 \\
\hline $\mathrm{HCO}_{3}^{-}$ & 211 & 32 & 268 & 61 & 206 & 32 & 244 & 61 & 218 & 3 & 220 & 215 & 247 & 13 & 268 & 232 \\
\hline $\mathrm{SO}_{4}{ }^{2-}$ & 275 & 88 & 563 & 67 & 284 & 88 & 563 & 67 & 325 & 38 & 366 & 269 & 144 & 29 & 173 & 128 \\
\hline $\mathrm{Cl}$ & 330 & 113 & 603 & 85 & 345 & 113 & 603 & 156 & 439 & 18 & 461 & 425 & 101 & 17 & 128 & 85 \\
\hline $\mathrm{NO}_{3}^{-}$ & 16.1 & 6.4 & 35 & 0 & 17 & 6.4 & 35 & 7.8 & 14 & 7 & 22 & 8 & 7.7 & 8 & 18 & 0 \\
\hline
\end{tabular}

in 2005 a small sampling survey was undertaken in those areas for which no information was available. In total, 32 determinations were made available from 11 boreholes from which pumped abstractions from the aquifer are still being made.

A summary of the physicochemical parameters is summarised of table $1 \mathrm{~A}$. In broad terms, and considering electrical conductivity (EC) to be the parameter representative of mineralization, one can appreciate that the mean is around 2300 $\mu \mathrm{S} \mathrm{cm} \mathrm{cm}^{-1}$, which indicates a certain degree of mineralization. Nonetheless, both the standard deviation $\left(900 \mu \mathrm{S} \mathrm{cm} \mathrm{cm}^{-1}\right)$ and the range between maximum and minimum EC values $\left(>3000 \mu \mathrm{S} \mathrm{cm}^{-1}\right)$ denote variability. The same table includes a characterisation of samples taken from the main exploitation sectors; samples from points outside of these areas are excluded. Accordingly, it is possible to highlight much more clearly that the variability in groundwater chemistry corresponds to spatial zoning of mineralization. The zone of greatest salinity is in the east of the Sierra de Crevillente, while less-mineralised water is taken from the Sierra del Rollo, where mean EC is $1000 \mu \mathrm{S} \mathrm{cm}^{-1}$.

Groundwater is characterised by high contents of $\mathrm{Cl}^{-}, \mathrm{Na}^{+}$y $\mathrm{SO}_{4}{ }^{2-}$. Sodium is the dominant cation in all the sectors (comprising between $70 \%$ of the total cations in the Tolomó sector and 52\% in Rollo), followed by calcium. With respect to the anions, chloride is most abundant in the Sierra de Crevillente, accounting for between $54 \%$ and $48 \%$. In contrast, bicarbonate predominates in the Rollo sector, though chloride content is also elevated. Based on these major 
ions one can identify two water types: sodium chloride in the Sierra de Crevillente and sodium bicarbonate-chloride in the Sierra del Rollo.

Everything indicates that the processes controlling the chemistry of these waters are the interaction processes between the groundwater and matrix rock (limestone and dolomite) and the dissolution of Keuper evaporites (gypsum and halite). The close correlation of $\mathrm{Cl}^{-}+\mathrm{SO}_{4}{ }^{2-}$ with $\mathrm{EC}\left(\mathrm{r}^{2}=0.9781\right)$ confirms that the salinity of the water is principally due to the presence of these anions, fig. 2a. Dissolution of the Triassic materials, outcropping along various borders and in the interior of the aquifer, as well as occurring at depth, where they form part of the base thrust fault, seems to provide evidence for the sodium chloride type that all the groundwater in this aquifer share. This is proof that the Keuper deposits in this region are extremely rich in $\mathrm{NaCl}$. The dissolution of these Triassic evaporites explains the origin of sodium and chloride, fig. $2 \mathrm{~b}$. The close fit of all the aquifer sampling points to the line $\mathrm{Na} / \mathrm{Cl}=1$ suggests that other processes, such as ion exchange, are insignificant. Both figures $2 \mathrm{a}$ and $2 \mathrm{~b}$ clearly differentiate samples from the Rollo sector, which points to a lesser influence of saline dissolution in this pumping zone.
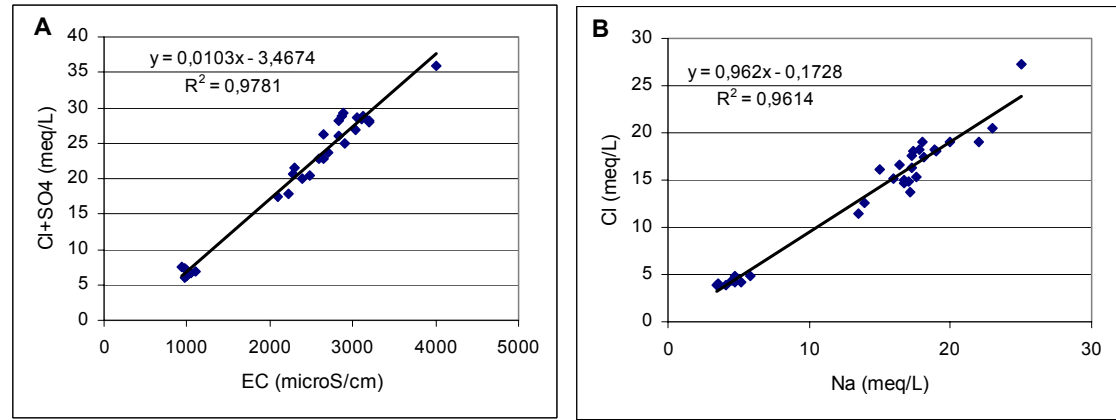

Figure 2: Chlorides + sulphates vs. electrical conductivity (a). Chlorides vs. sodium (b).

Lastly, although all the waters of the Sierra de Crevillente are generally more saline, those taken from boreholes in the interior of the Galería are the ones that exhibit highest sulphate concentrations. Mean values exceed $490 \mathrm{mg} \mathrm{L}^{-1}$, with individual values reaching $530 \mathrm{mg} \mathrm{L}^{-1}$, table 1 . This is as a local feature around these boreholes, which has been interpreted in previous studies as a possible consequence of variations in lithology within the Keuper facies itself, which may be more gypsiferous in the vicinity of the Galería $[10,1]$.

The relatively stable hydrodynamic situation that the aquifer has featured in recent years seems to be largely reflected in the water chemistry. Figure 3 shows the behaviour of EC in the Tolomó (T-6) and Rollo (R-2) sectors, as well as at borehole A-1, a sampling point outside of the exploitation areas established in this study. Boreholes A-1 and R-2 both possess complete records and they corroborate the marked stability in terms of mineralization. This same behaviour seems also to have occurred in T-6, though here, the lack of a continuous log, 


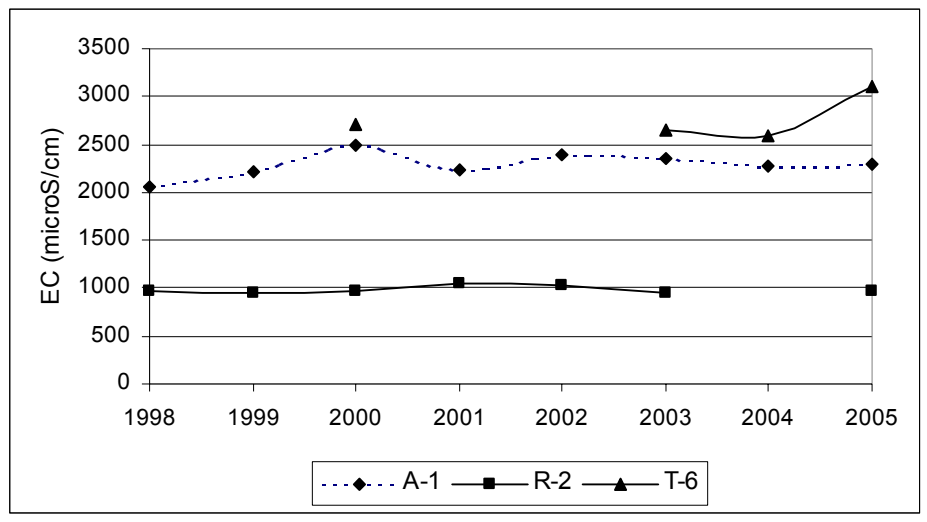

Figure 3: $\quad$ EC evolution in different wells of the Crevillente aquifer.

together with a rise in conductivity during 2005 means that the trend cannot be surely asserted. Finally, one of the Galería boreholes, not shown in the graph, gave values of $3050 \mu \mathrm{S} \mathrm{cm}^{-1}$ and $2870 \mu \mathrm{S} \mathrm{cm}^{-1}$ in 2001 and 2005 , respectively.

\section{Hydrochemical evolution in relation to overexploitation}

To achieve the aims of this study, it was necessary to search and compile all historic chemical analyses. Due to the lack of analytical determinations and objective information about the "original" physico-chemical characteristics of the Crevillente groundwater, it was impossible to establish with any certainty its chemical composition previous to exploitation of the aquifer by Man, nor the transformations that took place (or not) during the early years of intense abstractions.

The earliest reference to the physico-chemistry of these aquifer waters dates to the beginning of the seventies, and this relates chloride concentrations of just above $400 \mathrm{mg} \mathrm{L}^{-1}$, Andreu et al [4]. Bearing in mind that this was the only reference prior to the exploitation of the aquifer, one must suppose that, in spite of dealing with a karstic aquifer, the water in this zone exhibited a notable evaporitic influence, so that initially its facies would have to have been chloride bicarbonate or chloride.

Analytical data really become available after 1975 and so the influence of the intense abstractions on water quality can begin to be determined from this time. However, even then the aquifer was clearly overexploited, such that it had produced a drawdown of over $75 \mathrm{~m}$. An additional problem in interpreting historic data was that both temporal and spatial data were frequently very discontinuous.

In an attempt to overcome this problem, it was decided to treat the data globally. All determinations prior to 1983 were selected, this date being chosen since at this stage there was still no significant piezometric differences between the sectors of the aquifer. A total of 56 determinations, corresponding to 21 
boreholes, were available. Despite the fact that during the period 1975/83 there was dewatering over $100 \mathrm{~m}$ in the southern part of the aquifer, we consider that this period gives the clearest quantitative characterisation. Table 1B summarises the main results, using the same criterion used for the present-day analyses.

The results for the aquifer as a whole, table 1, give a mean EC of $1727 \mu \mathrm{S}$ $\mathrm{cm}^{-1}$, and a maximum of $2800 \mu \mathrm{S} \mathrm{cm}^{-1}$. Both statistics indicate, broadly speaking that, the mineralization of the pumped water at that time was less than at present. In terms of cations, sodium was the most abundant then and now. Mean concentrations were markedly lower than now (mean of $214 \mathrm{mg} \mathrm{L}^{-1}$ ) and the same is true for calcium. Contrary to expectations, magnesium was present in greater quantity. For the anions, chloride and sulphate exceeded bicarbonate content. A comparison with the present day indicates that concentrations have considerably increased. In short, the waters were less saline during the earlier period analysed. This confirms that an increase in mineralization has occurred over time, due to the continuing overabstraction.

Grouping the samples between the established sectors allows the manner in which salinization has increased to be specified. Table 1 indicates that the Tolomó part is the most-affected by deterioration in water quality. A rise in the mean EC (>1200 $\left.\mu \mathrm{S} \mathrm{cm}^{-1}\right)$ has basically been propitiated by an enrichment in sodium and chloride. These ions have caused a doubling compared to pre-1983 values. Sulphate and calcium have also risen, though to a lesser degree. However, it must be remembered that any comparison between parameters shown in table 1 must be relative, since some of the analyses prior to 1983 come from boreholes that are not represented in the post-2000 grouping - due to their having been abandoned in the interim because of salinization. There is evidence that numerous boreholes were abandoned as a direct result of the deterioration in water quality, which meant the water was no longer suitable for irrigation of table grapes.

The increased in salinity has taken place gradually as the groundwater depletion progressed. Figure 4 represents the evolution of chloride over time for three boreholes in Tolomó, and of these, water continues to be abstracted only from $\mathrm{n}^{\mathrm{o}}$ 15. The other two bores were abandoned when the chloride concentrations exceeded $1 \mathrm{~g} \mathrm{~L}^{-1}$. The trend lines drawn indicate that not all of the boreholes suffered a saline enrichment simultaneously. Generally, salinization has occurred most rapidly in boreholes on the south-eastern edge of the aquifer, where the Keuper deposits outcrop. Nonetheless, the presence of Triassic deposits at the bottom of some boreholes has accelerated the rate of deterioration in water quality. Unfortunately, the lack of data impedes close scrutiny on the graph, though it is possible to observe a drop of almost $100 \mathrm{mg} \mathrm{L}^{-1}$ in chloride content between 1996 and 1990 in borehole $n^{\circ} 9$.

In the Galería area, as well, is confirmation of a rise in salinity between the two periods studied, though of smaller magnitude. In contrast to the Tolomó sector, the abandonment of boreholes in this part of the aquifer was principally due to problems of a drop in flow. On the other hand, data for both periods comes from the same boreholes and so a comparison between them is much more representative. Greatest increases were seen for the chloride ion - by 
approximately $42 \%$. Sodium underwent an similar increase $(39 \%)$. Particular to this zone of this aquifer is the significant rise in sulphates (of more than $150 \mathrm{mg}$ $\mathrm{L}^{-1}$ in the mean value), a feature that is not seen in Tolomó, and which is probably due to the presence of facies richer in gypsum in this environment, as mentioned above. All in all, using chloride concentrations prior to the onset of pumped abstractions (400 $\mathrm{mg} \mathrm{L}^{-1}$ ), it is estimated that the overabstractions have caused a rise in chloride of slightly more than $50 \%$ in this part of the aquifer.

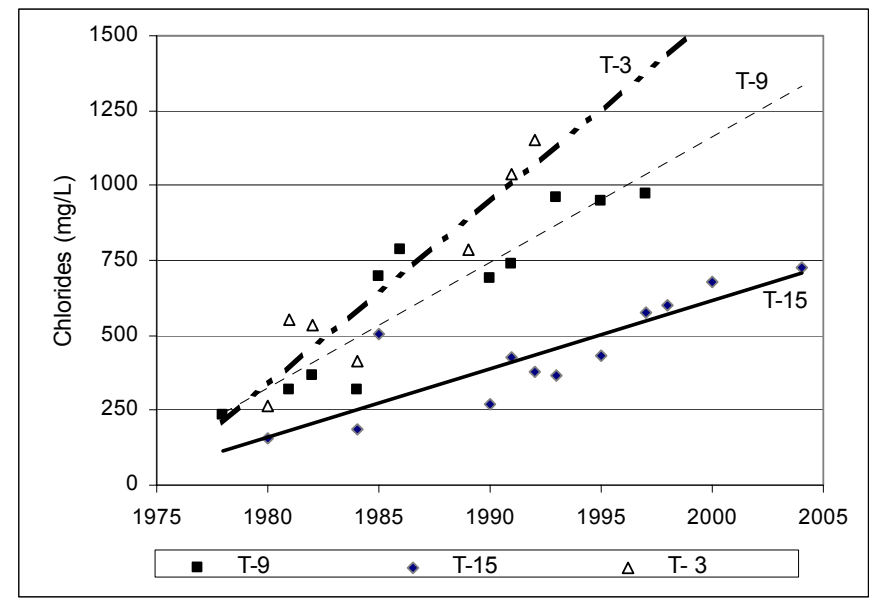

Figure 4: Chloride evolution in different wells of the Tolomó area. The trend line for each well can be seen, which shows the rate of decline in quality.

In the Sierra del Rollo sector it is more difficult to draw conclusions. Everything points to the increase in electrical conductivity as being due to a greater presence of sodium and chloride ions. However, a fall in the mean magnesium and sulphate concentrations is observed. It is highly likely that these divergences may be due to the fact that the sets of sampling points used to determine the means of the two periods did not fully coincide. In any event, the fact that the decline has been less severe, together with the fact that the evaporite rocks are further away and that this part of the aquifer probably accommodates circulating flows that have a lower residence time, leads to the hypothesis that these factors are the reason that this sector shows less evidence of a decline in water quality $[10,1]$.

\section{Conclusions}

Over more than forty years the Crevillente aquifer has been subjected to intense exploitation. However, in recent years the level of abstractions have reduced 
considerably, which has led the system to enter a new hydrodynamic phase, although there are residual pockets hat are still designated as overexploited.

Under this hydrodynamic scenario, a new characterisation of its waters has been undertaken. The results indicate that, in general, the waters are quite highly mineralised, since it is a karstic aquifer. This elevated mineralisation is basically due to dissolution of the evaporite deposits found within the aquifer and which combine by means of the typical interactions between water and carbonate rock. This mineralisation is not consistent through the aquifer; rather, there is clear spatial zoning, with greater influence in the southern part. The geological characteristics are highlighted and the presence of evaporite deposits are two important factors that determine the water quality.

Finally, it has been confirmed that the overexploitation of the Crevillente aquifer has provoked enrichment in minerals throughout virtually its entirety. According to the results described above, each sector has evolved separately as a response to the exploitation within it. In places where Keuper facies are present at depth, the water has become salinised to a greater degree. Thus, the eastern part of the Sierra de Crevillente is one of the sectors most affected by decline in water quality and the sector in which most boreholes have had to be abandoned as a result.

\section{Acknowledgements}

This study has been undertaken within the framework of the GV07/143 Project of the Generalitat Valenciana and the IGCP 513 UNESCO project. We would like to thank the Comunidad de Regantes Virgen de las Nieves de Aspe, and Galería de los Suizos.

\section{References}

[1] Andreu. J. M., Contribución de la sobreexplotación al conocimiento de los acuíferos kársticos de Crevillente, Cid y Cabeçó d'Or (provincia de Alicante). Doctoral Ph. Thesis, Universidad de Alicante, 377, 1997.

[2] Andreu J.M. \& Bru, C., Water management in Alicante: Hydrogeology, Economics, Environment, and main institutions in the Vinalopó basin and Campo de Alicante. Technical Field Trip In: International Symposium on Groundwater Sustainability (ISGWAS), 27, 2006.

[3] Andreu, J. M., Pulido-Bosch, A. \& Estévez, A., Aquifer overexploitation in Alicante (Spain). $3^{\text {rd }}$ International Conference on Future Groundwater Resources at Risk. Lisbon (Portugal), pp. 713-720, 2001.

[4] Andreu, J. M., Estévez, A., García-Sánchez, E. \& Pulido-Bosch, A., Caracterización de la explotación en el sector occidental del acuífero de Crevillente (Alicante). Geogaceta, 31, pp. 59-62, 2002.

[5] Aragonés, J. M., Corchón, F. \& Santafé, J.M., Planes de ordenación de acuíferos sobreexplotados. La experiencia de la Sierra de Crevillente 
(Alicante). La Sobreexplotación de Acuiferos eds. Pulido-Bosch et al, Temas Geológico-Mineros, 10, pp. 177-191, 1981

[6] Corchón, F, Rodríguez-Estrella, T. \& Sánchez-Almohalla, E. (1989). Datos básicos para la realización del Plan de Ordenación del Acuífero sobreexplotado de Crevillente. La Sobreexplotación de Acuiferos eds. Pulido-Bosch et al, Temas Geológico-Mineros, 10, pp. 471-483, 1981.

[7] Custodio, E., Aquifer overexploitation: what does it mean? Hydrogeology Journal, 10(2), pp. 254-277, 2002

[8] Pulido-Bosch, A., L'exploitation minière de l'eau dans l'aquifère de la Sierra de Crevillente et ses alentours (Alicante, Espagne) 18th Cong. IAH Hydrogeology in the Service of Man, Cambridge, pp. 142-149, 1985.

[9] Pulido-Bosch, A., The overexploitation of some karstic aquifers in the province of Alicante (Spain). XXIII Congr. A.I.H. Sobrexplotación de acuiferos, Santa Cruz de Tenerife, pp. 557-561, 1991.

[10] Pulido-Bosch, A., Morell, I. \& Andreu, J.M., Hydrogeochemical effects of groundwater mining of the Sierra de Crevillente Aquifer (Alicante, Spain). Environmenta. Geoogy, 26, pp. 232-239, 1995.

[11] Solís, L. A., Rodríguez-Estrella, T., Cabezas, F. \& Senet, M., Cálculo de la "curva de explotación" en el sistema acuífero de la Sierra de Crevillente (Alicante). Hidrogeol. Rec. Hidraul. XI, Madrid, pp. 345-358, 1983. 